\title{
ПРОБЛЕМЫ КВАЛИФИКАЦИИ МЕЛКОГО ВЗЯТОЧНИЧЕСТВА
}

\author{
(СПрозоров А. М., Томский государственный университет, г. Новосибирск, Россия, \\ prozrf@gmail.com
}

\section{PETTY BRIBERY QUALIFICATION ISSUES}

\author{
CProzorov A., Tomsk State University, Novosibirsk, Russia, prozrf@gmail.com
}

Аннотация. Статья посвящена проблемам квалификации взяточнических преступлений. Выделены проблемы справедливой уголовно-правовой оценки и соразмерного наказания групповых преступлений при мелком взяточничестве; проблемы квалификации посредничества во взяточничестве; вопрос выбора уголовно-правовой квалификации мелкого интернационального подкупа в зависимости от субъекта преступления. Рассматривается проблема квалификации мелкого взяточничества и оценка действий посредника в этом преступлении. Предлагаются возможные варианты квалификации на конкретных примерах.

Abstract. The article is devoted to the problems of the qualification of petty bribery crimes. The article also touches upon the problem criminal low assessment and proportionate punishment of group crimes of petty bribery; the problem of the qualification of mediation in bribery; issue of choosing a criminal qualification of petty international bribery depending on the subject of the crime. The problem of petty bribery qualification and assessment of actions mediator in this crime. Possible qualification options are offered with specific examples.

Ключевые слова: квалификация взяточничества, посредничество во взяточничестве, мелкое взяточничество.

Keywords: qualification of bribery, mediation in bribery, petty bribery.

В современном мире коррупция является одной из наиболее острых социальноэкономических проблем, универсальный характер которой требует адекватной реакции со стороны государства [4].

В продолжение поступательной тенденции противодействия коррупции законодатель к триаде норм о взяточничестве (ст. ст. 290, 291, 291.1 УК РФ) не так давно криминализировал мелкое взяточничество - ст. 291.2 УК РФ.

Однако анализ действующего законодательства об ответственности за мелкое взяточничество в векторе его практического применения убедительно показывает, что недочеты в конструкции уголовно-правовой нормы оказывают огромное влияние на ее толкование.

В первую очередь обращает на себя внимание формирование состава ст. 291.2 УК РФ по своему конструированию который полностью отличается от норм взяточничества. К числу проблемных вопросов невозможность справедливой уголовно-правовой оценки посредничества в случае мелкого взяточничества, трудности квалификации групповых преступлений и др. 
На первый взгляд введение в Уголовный Кодекс ст. 291.2 является обоснованным, целью которого видится назначение справедливого и соразмерного наказания, т. к. из статистических данных, представленных Верховным Судом РФ за последнее время большинство лиц были осуждены за преступления, где сумма взятки не превышала 10000 рублей.

Статья 6 УК РФ гласит, что «наказание и иные меры уголовно-правового характера, применяемые к лицу, совершившему преступление, должны быть справедливыми, то есть соответствовать характеру и степени общественной опасности преступления, обстоятельствам его совершения и личности виновного»

Однако, рассмотрим в качестве примера получение взятки группой лиц по предварительному сговору. Если размер взятки составит 10500 руб. то действия коррупционеров будут квалифицироваться по ч. 5 ст. 290 с наказанием в виде штрафа в размере от двух миллионов до четырех миллионов рублей либо лишения свободы на срок от семи до двенадцати лет со штрафом в размере до шестидесятикратной суммы взятки или без такового и с лишением права занимать определенные должности или заниматься определенной деятельностью на срок до десяти лет или без такового.

В случае если размер взятки будет 9500 р. то при тех же условиях лица понесут ответственность по ч. 1 ст. 291.2 УК РФ (через ст. 63 УК РФ) с наказанием в штрафом в размере до двухсот тысяч рублей или в размере заработной платы или иного дохода осужденного за период до трех месяцев, либо исправительными работами на срок до одного года, либо ограничением свободы на срок до двух лет, либо лишением свободы на срок до одного года.

Рассматривая эти два примера, можно утверждать, что при совершении практически схожих преступлений, в первом примере деяние будет квалифицироваться как особо тяжкое, а во втором - как небольшой тяжести. В итоге выход за пределы суммы мелкого взяточничества увеличивает санкцию в виде штрафа до 20 раз, а в виде лишения свободы до 12 раз. Но как подчеркивает профессор Московского государственного института международных отношений (Университета) Министерства иностранных дел Российской Федерации доктор юридических наук Сидоренко Э. Л. - «гораздо более опасным является стирание различий между групповыми и индивидуальными преступлениями, взяточничеством, сопряженным и не сопряженным с вымогательством, связанным и не связанным с незаконными действиями (бездействием) должностных лиц, только лишь на том основании, что виновный не превысил установленный в ст. ст. 204.2 и 291.2 УК РФ размер мелкой взятки» [1, с. 28].

Напрашивается вывод, что законодатель выделяет размер взятки перед какими-либо другими признаками мелкого взяточничества, которые могут оказать влияние на уголовно правовую оценку преступления. Также отсюда следует, что, несмотря на выбранный государством вектор борьбы с коррупцией, уголовная ответственность определенной категории взяточников снизится. При этом с другой стороны законодателем и Пленумом Верховного Суда РФ в Постановлении от 9 июля 2013 г. №24 «О судебной практике по делам о взяточничестве и об иных коррупционных преступлениях» не обозначена минимальная сумма взятки, что ставит правоприменителя перед коллизией, ограничивающей мелкое взяточничество от малозначительного деяния.

Также ставит в тупик ученых и практиков проблема статуса субъекта преступления [47]. С одной стороны, в роли взяткополучателя выступает должностное лицо, указанное в примечании к ст. 285 УК РФ, а также иностранное лицо или должностное лицо международной организации. С другой стороны, согласно ч. 2 примечания к ст. 290 УК РФ 
определение иностранного должностного лица и должностного лица публичной международной организации проецируется на определенный список статей, в число которых ст. 291.2 УК РФ не входит. Отсюда возникает вопрос выбора уголовно-правовой квалификации мелкого интернационального подкупа.

Возможны две ситуации. Первая, считать мелкое взяточничество как специальный привилегированный состав коррупции, а ст. 290 УК РФ - как общий состав. Тогда иностранное лицо, обладающее признаками специального субъекта, будет подпадать под ст. 290 УК РФ, даже при условии, если сумма подкупа будет меньше 10 тыс. рублей, но при этом наказание за такое преступление будет намного серьезнее, чем ответственность российского государственного служащего. Вторая основана на принципе гуманизма. Например, если иностранец, являющимся спецсубъектом не подпадает под действие привилегированного состава, оно не может подлежать ответственности по общему составу.

Не менее важной проблемой квалификации мелкого взяточничества является оценка действий посредника в этом преступлении [8]. Из ст. 291.1 УК РФ следует, что к уголовной ответственности может быть привлечено лицо при посредничестве во взятке более 25 тыс рублей (значительный размер). Отсюда следует, что действия посредника в мелком взяточничестве не является уголовно наказуемым деянием. Вместе с тем посредник играет важную роль - договаривается о самой передачи, при этом сам нередко не знает о сумме взятки [9-10]. Напрашивается криминализация пособничества в мелком взяточничестве, ведь эта недоработка законодателя дает коррупционерам лазейку для безнаказанного совершения преступлений. Например, посредник получает от взяткодателя 210 тыс руб., из 200 тыс руб. забирает себе в качестве вознаграждения, а 10 тыс рублей отдает взяткополучателю. В таком случае в действиях посредника отсутствует состав преступления, а действия взяткополучателя квалифицируются по ст. 291.2 УК РФ — мелкое взяточничество.

\section{Список литературы:}

1. Сидоренко Э. Л. Проблемы квалификации мелкого взяточничества // Мировой судья. 2017. №10. С. 24-29.

2. Михайлов В. И. Эволюция законодательства об ответственности за взяточничество // Уголовное право. 2016. №5. С. 46-56.

3. Анощенкова С. В., Геворкян С. С. Взяточничество мелкое - вопросы крупные // Законность. 2017. №3. С. 43-45.

4. Lambert-Mogiliansky A., Majumdar M., Radner R. Strategic analysis of petty corruption: Entrepreneurs and bureaucrats // Journal of Development Economics. 2007. V. 83. №2. P. 351-367. https://doi.org/10.1016/j.jdeveco.2006.06.002.

5. Lambert-Mogiliansky A., Majumdar M., Radner R. Petty corruption: A game-theoretic approach // International Journal of Economic Theory. 2008. V. 4. №2. P. 273-297. https://doi.org/10.1111/j.1742-7363.2008.00078.x.

6. Yoo S. H. Petty corruption // Economic Theory. 2008. V. 37. №2. P. 267-280. https://doi.org/10.1007/s00199-007-0299-3.

7. Элекина С. В. Предмет взяточничества по современному уголовному праву России // Юридический вестник Самарского университета. 2018. Т. 4. №4. Р. 159-165. https://doi.org/10.18287/2542-047X-2018-4-4-159-165.

8. de Dieu Basabose J. The Concept of Corruption // Anti-corruption Education and Peacebuilding. Cham: Springer, 2019. P. 13-45. https://doi.org/10.1007/978-3-030-03365-1_2. 
9. Sampson S. Anti-corruption: Who Cares? // Challenges in Managing Sustainable Business. Palgrave Macmillan. Cham, 2019. P. 277-294. https://doi.org/10.1007/978-3-319-93266-8_12.

10. Rose-Ackerman S. Corruption \& purity // Daedalus. 2018. V. 147. №3. P. 98-110. https://doi.org/10.1162/daed_a_00505.

\section{References:}

1. Sidorenko, E. L. (2017). Problemy kvalifikatsii melkogo vzyatochnichestva. Mirovoi sud'ya, (10). 24-29. (in Russian).

2. Mikhailov, V. I. (2016). Evolyutsiya zakonodatel'stva ob otvetstvennosti za vzyatochnichestvo. Ugolovnoe parvo, (5). 46-56. (in Russian).

3. Anoshchenkova, S. V., \& Gevorkyan, S. S. (2017). Vzyatochnichestvo melkoe - voprosy krupnye. Zakonnost', (3). 43-45. (in Russian).

4. Lambert-Mogiliansky, A., Majumdar, M., \& Radner, R. (2007). Strategic analysis of petty corruption: Entrepreneurs and bureaucrats. Journal of Development Economics, 83(2), 351-367. https://doi.org/10.1016/j.jdeveco.2006.06.002.

5. Lambert-Mogiliansky, A., Majumdar, M., \& Radner, R. (2008). Petty corruption: A gametheoretic approach. International Journal of Economic Theory, 4(2), 273-297. https://doi.org/10.1111/j.1742-7363.2008.00078.x.

6. Yoo, S. H. (2008). Petty corruption. Economic Theory, 37(2), 267-280. https://doi.org/10.1007/s00199-007-0299-3.

7. Elekina S. V. (2018). Predmet vziatochnichestva po sovremennomu ugolovnomu pravu Rossii [Subject of bribery under the modern criminal law of Russia]. Iuridicheskii vestnik Samarskogo universiteta [Juridical Journal of Samara University], 4(4), 159-165. DOI: https://doi.org/10.18287/2542-047X-2018-4-4-159-165 (in Russian).

8. de Dieu Basabose, J. (2019). The Concept of Corruption. In Anti-corruption Education and Peacebuilding, 13-45. Springer, Cham. https://doi.org/10.1007/978-3-030-03365-1_2.

9. Sampson, S. (2019). Anti-corruption: Who Cares? In: Challenges in Managing Sustainable Business, 277-294. Palgrave Macmillan, Cham. https://doi.org/10.1007/978-3-31993266-8_12.

10. Rose-Ackerman, S. (2018). Corruption \& purity. Daedalus, 147(3), 98-110. https://doi.org/10.1162/daed_a_00505.

Работа поступила

в редакциию 11.03.2019 2.
Принята к публикациии 15.03.2019 2.

Ссылка для циитирования:

Прозоров А. М. Проблемы квалификации мелкого взяточничества // Бюллетень науки и практики. 2019. Т. 5. №4. С. 378-381. https://doi.org/10.33619/2414-2948/41/54.

Cite as (APA):

Prozorov, A. (2019). Petty Bribery Qualification Issues. Bulletin of Science and Practice, 5(4), 378-381. https://doi.org/10.33619/2414-2948/41/54. (in Russian). 